GEOLOGICA BALCANICA 50 (3), Sofia, December 2021, pp. 29-35.

\title{
Risk assessment of geological disaster in the region of Primorsko Municipality
}

\author{
Antoaneta Frantzova \\ Geological Institute, Bulgarian Academy of Sciences, Acad. G. Bonchev Str., Bl. 24, 1113 Sofia, Bulgaria; \\ e-mail: afrantzova@gmail.com
}

(Received: 25 October 2021; accepted in revised form: 23 November2021)

\begin{abstract}
Risk assessment methodology is described in detail and applied for assessing the geological hazard for potential landslides and earthquakes. This methodology follows the guidelines of ISO 31010 and the JRC recommendations, and is applied for the first time in Bulgaria. The obtained results have high practical applicability. The flexibility of the methodology allows the final result to be presented as either a risk matrix or risk profiles. It depends on the specific tasks, issues and scientific problems that need to be solved.
\end{abstract}

Frantzova, A. 2021. Risk assessment of geological disaster in the region of Primorsko Municipality. Geologica Balcanica 50 (3), 29-35.

Keywords: risk assessment methodology, geological hazards, landslides, earthquakes.

\section{INTRODUCTION}

Bulgaria is located in an active orogenic zone with complex tectonic structure, a variety of geological formations and sharp relief changes, and the whole spectrum of destructive and hazardous processes are present. Most popular European and world practices for risk assessment are incorporated in the present research. The main aim is to present an enhanced complex method for risk (multi-risk) assessment of natural hazard which incorporates the most used applications and practices (i.e., Inter-American Development Bank, World Bank, United Nations International Strategy for Disaster Reduction, Joint Research Center - European Commission).

Primorsko Municipality (Fig. 1) occupies the southern part of the Bulgarian Black Sea coast (Burgas District). It is a resort and tourism center. The relief is mostly hilly, with a dense network of ravines. The main drainage arteries are the Dyavolska and Ropotamo rivers. The average altitude is 16 me- ters above sea level. The relief is low in the coastal zone and mountainous in the Strandzha Mountain zone. The climate is continental, influenced by the Black and the Mediterranean seas. The summer is sunny and warm, with refreshing winds in daytime and relatively high night temperatures. The average temperature in July is $23-24^{\circ} \mathrm{C}$. The maximum temperature rarely reaches over $32-33^{\circ} \mathrm{C}$. The vegetation has strongly manifested Mediterranean characteristics.

From a regional point of view, the area of Primorsko Municipality is a part of the Srednogorie tectonic zone (Dabovski et al., 2009). Upper Cretaceous sediments and volcanic rocks (e.g., tuffs and trachytes) predominate (Petrova et al., 1992). North of the town of Primorsko, a fragment of an intrusive body of syenites and quartz-syenites (i.e., the Rosen pluton) occurs. The Neogene is represented by sandstones, limestones and clays (Galata Formation). The Quaternary deposits cover mainly river valleys, estuaries and the Black Sea coast. Lake- 


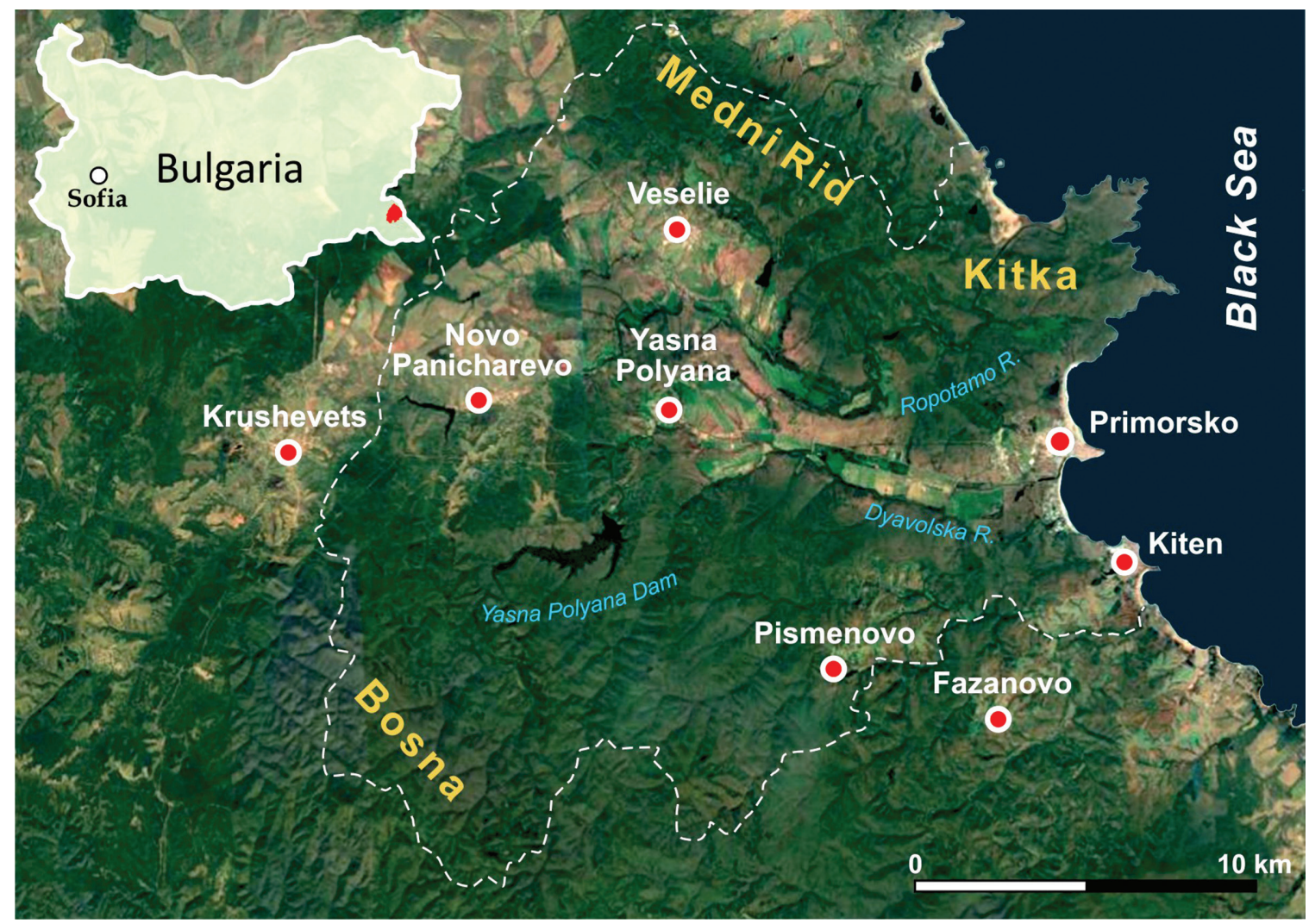

Fig. 1. Location map of Primorsko Municipality (map sourced from Google Earth).

swamp (sands, clays, peat), alluvial (gravel, sands, clays) and modern sea deposits (beach sands) are observed within the considered area.

According to the map of geological hazards in Bulgaria (Iliev-Broutchev, 1994), the risk in the area of Primorsko Municipality can be divided into several classes by the natural hazard-triggering threats (geological and meteorological) as follows: 1) low level - erosion, salt water intrusion (salinization), coastal depositions, abrasion; 2) middle level - heavy rains, winds, blizzards hails; 3) high level storm surges, flash floods and especially earthquake effects and landslides, which are under investigation in the present paper.

\section{METHODOLOGY USED FOR THE RISK ASSESSMENT PROCESS}

Risk is the probability of harmful consequences or expected losses (deaths, injuries, damages of properties, livelihoods and environment economic activity disruption) resulting from interactions between natural or human-induced hazards and opportune conditions. It refers to the expected losses from a specific hazard to a given element at risk over a specified time period in the future. The first definition was given by Blaikie et al. (1994), according to which risk is the product of hazard potential and vulnerability. According to UNISDR (2002) and UNDP (2004), risk is a function of hazard, vulnerability and coping capacity, whereas, according to JRS recommendations (see Poljansek et al., 2021), it is a function of hazard, exposure and vulnerability.

Risk assessment is a disaster preparedness activity and a main tool for the risk management of natural disasters (Fig. 2). The relationship between vulnerability, hazards and coping capacity are presented in Table 1 and Fig. 3.

Hazard is usually expressed by the probability of occurrence for a specific time period (UNDP/ DMTP, 2002). Vulnerability has the following aspects: economic, social, environmental, physical and demographic. While vulnerability focuses mainly on the communities and people, the coping capacity is a measure of prevention, mitigation, preparation, response, rehabilitation and reconstruction (IADB/ GTZ, 2003, UNISDR, 2004; IADB, 2005). 


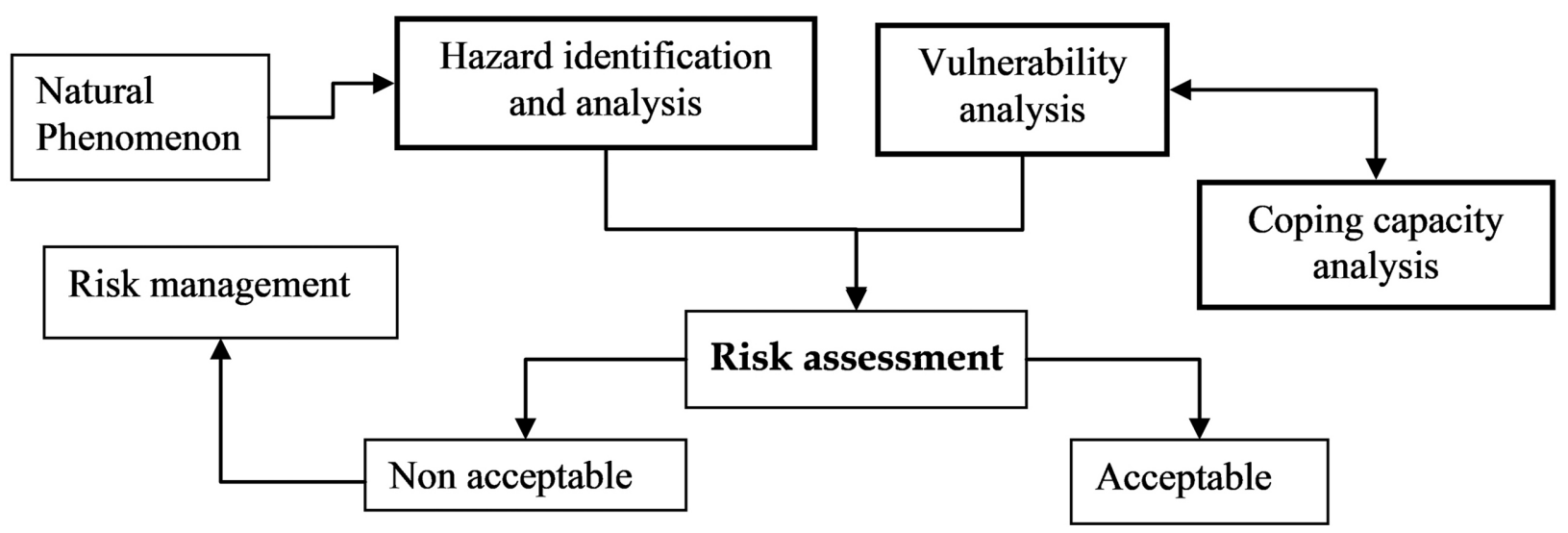

Fig. 2. Risk assessment (UNDP, 2004).

Table 1

Relationship between vulnerability and coping capacity (after Frantzova, 2017)

\begin{tabular}{c|c|c|c|c|c}
\hline \multirow{2}{*}{ Vulnerability } & \multicolumn{5}{|c}{ Coping capacity } \\
\cline { 2 - 6 } & Very low & Low & Medium & High & Very high \\
\hline Very high & Very high & Very high & High & Medium & Medium/Low \\
High & High & High & Medium/High & Low/Medium & Low \\
Medium & Medium & Medium & Low/Medium & Low & Very low \\
Low & Low & Low & Very low & Very low & Very low \\
Very low & Very low & Very low & Very low & Very low & Very low \\
\hline
\end{tabular}

\begin{tabular}{|c|c|c|c|c|c|}
\hline Very high & $\begin{array}{r}6 \\
(102,255,255) \\
\end{array}$ & $\begin{array}{r}7 \\
(188,112,0) \\
\end{array}$ & $\begin{array}{r}8 \\
(255,87,91) \\
\end{array}$ & $\begin{array}{r}9 \\
(184,0,0)\end{array}$ & $\begin{array}{r}10 \\
(133,39,113) \\
\end{array}$ \\
\hline High & $(0,102,0)$ & $\begin{array}{r}6 \\
(93,174,255) \\
\end{array}$ & $(254,127,0)$ & $(255,139,142)$ & $(255,51,0)$ \\
\hline Medium & $\begin{array}{r}4 \\
(234,228,0)\end{array}$ & $\begin{array}{r}5 \\
(108,254,68)\end{array}$ & $\begin{array}{r}6 \\
(67,130,193)\end{array}$ & $\begin{array}{r}7 \\
(255,178,101)\end{array}$ & $\begin{array}{r}8 \\
(255,183,185)\end{array}$ \\
\hline Low & $\begin{array}{r}3 \\
(255,175,255) \\
\end{array}$ & $\begin{array}{r}4 \\
(255,255,102) \\
\end{array}$ & $\begin{array}{r}5 \\
(124,154,0) \\
\end{array}$ & $\begin{array}{r}6 \\
(47,47,255) \\
\end{array}$ & $\begin{array}{r}7 \\
(255,221,125) \\
\end{array}$ \\
\hline Very low & $\begin{array}{r}2 \\
(255,255,255) \\
\end{array}$ & $\begin{array}{r}3 \\
(255,221,255) \\
\end{array}$ & $\begin{array}{r}4 \\
(255,255,204) \\
\end{array}$ & $\begin{array}{r}5 \\
(51,204,51) \\
\end{array}$ & $\begin{array}{r}6 \\
(0,51,153)\end{array}$ \\
\hline Hazard/Vulnerability & Very low & Low & Medium & High & Very high \\
\hline
\end{tabular}

1 Very low<smiles>[13CH3]</smiles>
Low

\section{5}

67

Medium
89 High

Very high

Fig. 3. Risk matrix (Schmidt-Thomé, 2004). 


\section{RISK ASSESSMENT METHODOLOGY APPLIED FOR PRIMORSKO MUNICIPALITY}

According to the landslide zoning of the Bulgarian Black Sea coast, Primorsko Municipality falls into the southern landslide zone and the subzone of landslides southern from Burgas (Konstantinov et al., 1992; Bruchev et al., 2007; Frangov et al., 2011; Dobrev et al., 2013; Berov et al., 2016, 2020; Ivanov et al., 2017b, 2020). The main destabilizing factors are sea erosion, erosion and fluctuations in groundwaters. Data for local and regional seismicity are taken from the works of Ranguelov (2011), Solakov et al. (2014), Simeonova et al. (2006), as well as from the seismic zonation of Bulgaria (NIGGG, 2009), and seismic codes. The evaluation of geological risk itself is preceded by a number of other geological assessments: susceptibility, vulnerability and hazard (Lakov et al., 2002; Ivanov et al., 2017a; Bruchev, 2018).

The Inter-American Development Bank and Deutsche Gesellschaft für Technische Zusammenarbeit (IADB/GTZ, 2003) methodology was chosen for the risk assessment for Primorsko Municipality because of its flexibility and adaptability. It uses four risk factors (i.e., hazards, exposure, vulnerability and coping capacity) and is fully compat- ible with the United Nations, World Bank and Joint Research Center recommendations.

\section{Developed and adapted methodology for risk and multi-risk assessment}

The newly developed and adapted herein methodology for risk and multi-risk assessment includes five risk factors: hazards, exposure, vulnerability, coping capacity and risk perception (Fig. 4). Therefore, the risk profile for the given selected area is expressed as:

$$
\mathrm{R}=\mathrm{wH}+\mathrm{wE}+\mathrm{wV}+\mathrm{wRP}-\mathrm{wCC},
$$

where $\mathrm{H}, \mathrm{E}, \mathrm{V}$ and $\mathrm{CC}$ are the values of the hazard, exposure, vulnerability and coping capacity, and RP is the risk perception; $\mathrm{H}_{1}, \mathrm{H}_{2}, \mathrm{E}_{1}, \mathrm{E}_{2}, \mathrm{~V}_{1}, \mathrm{~V}_{2}$ and $\mathrm{CC}_{1}$, $\mathrm{CC}_{2}$, respectively, refer to the scaled values of the indicators; $\mathrm{w}_{\mathrm{i}}$ is the weighting coefficient. The total sum of the weighting coefficients must be equal to 100 .

The total number of indicators used to assess the risk profiles are over 70, including climate change and Global Change Syndromes (WGBU, 1998), specific to particular natural hazards for selected areas. Five classification characteristics associated with risk perception are included as indicators for risk assessment.

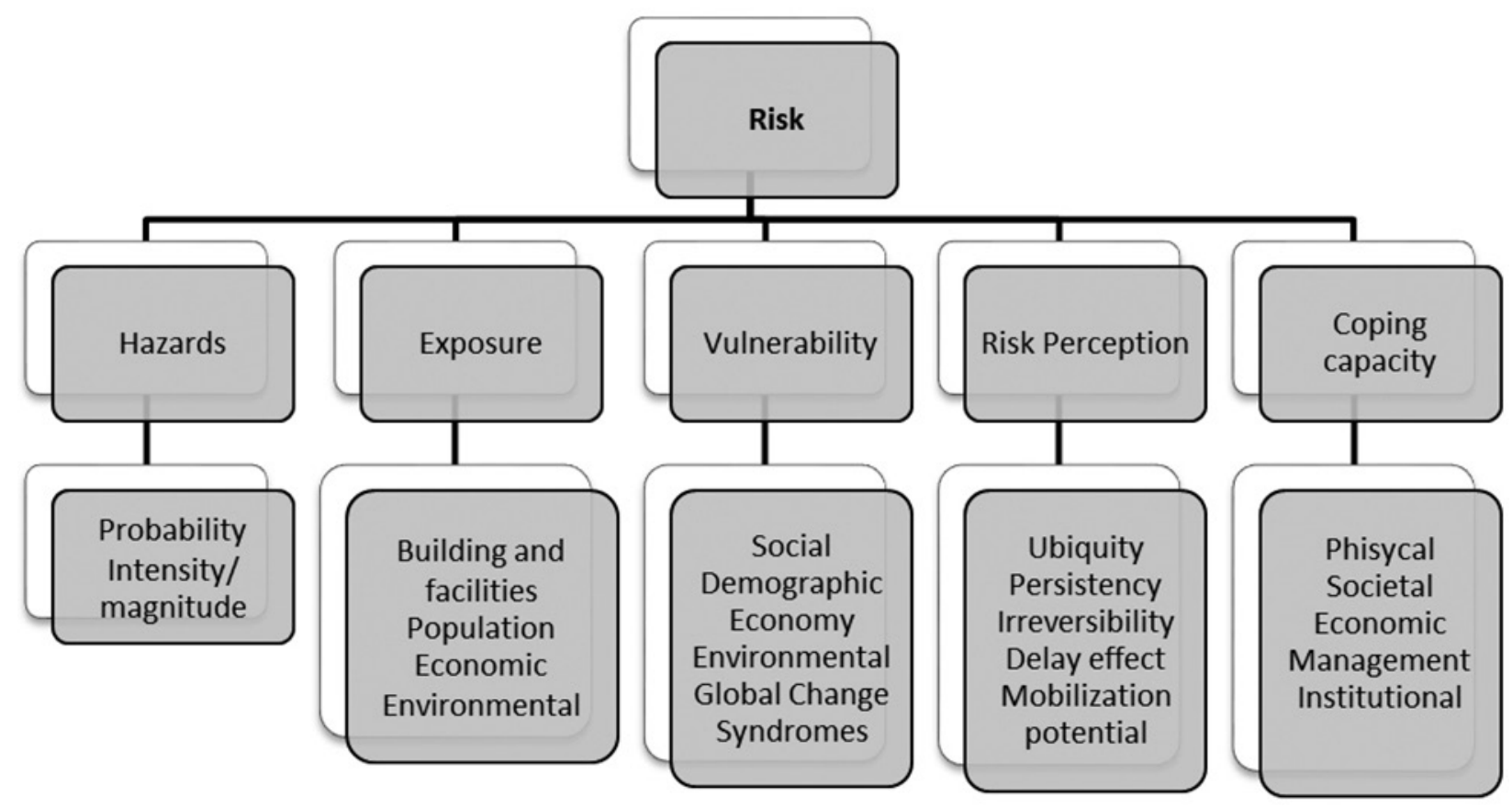

Fig. 4. Adapted methodology (Frantzova, 2017). 


\section{RESULTS}

The risk profile for Primorsko Municipality is expressed as:

$$
\begin{gathered}
\mathrm{R}=0.32 \times \mathrm{H}+0.35 \times \mathrm{E}+0.34 \times \mathrm{V}+ \\
0.34 \times \mathrm{RP}-0.35 \times \mathrm{CC} .
\end{gathered}
$$

The weighting coefficients vary for the different factors (hazard, exposure, vulnerability, copping capacity and risk perception). It is assumed that some of them have a greater importance in risk assessment and require the greatest attention. The general algorithm for multi-risk assessment is a set of consecutive operations described by Frantzova (2017). Result and risk levels are presented in Figs 5, 6 and Table 2. The risk from landslides and earthquakes is very low due to very low hazards and exposure. Risk levels are defined in Table 2.

\section{Confidence level}

Assessments of confidence are based on the expert's judgment and should provide supporting evidence and references for each conclusion. Confidence is expressed qualitatively and ranges from low confidence (inconclusive evidence or disagreement among experts) to very high confidence (strong evidence and high consensus). Confidence levels are reported even when they are low. Confidence should not be interpreted probabilistically, as it is distinct from statistical likelihood. The four confidence levels used herein are: 1) very high: strong evidence (established theory, multiple sources, consistent results, well-documented and accepted

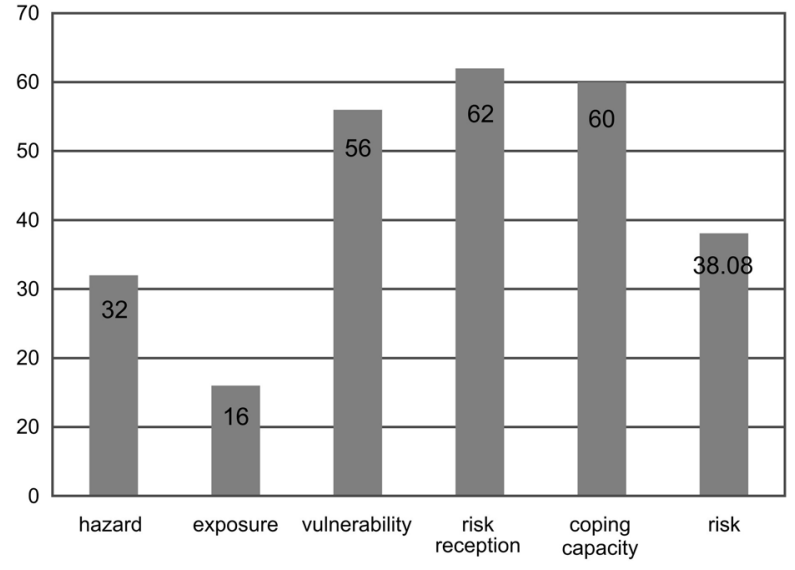

Fig. 5. Landslide risk profile (Primorsko Municipality).

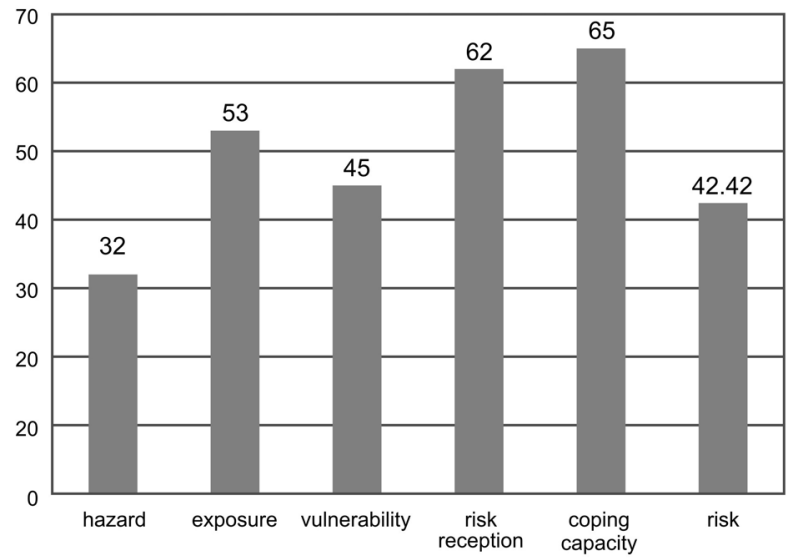

Fig. 6. Earthquake risk profile (Primorsko Municipality).

Table 2

Description of risk levels

\begin{tabular}{c|l}
\hline Risk levels & \multicolumn{1}{c}{ Description } \\
\hline Very low (33-46) & No casualties, damages to buildings, facilities or infrastructure are expected. \\
\hline Low (47-60) & $\begin{array}{l}\text { No casualties or injuries are expected; non-structural damage to buildings; 0.05\% up to 0.08\% } \\
\text { expected economical losses from the municipal budget. }\end{array}$ \\
\hline Medium (61-73) & $\begin{array}{l}\text { Up to 0.5\% affected population (not death toll or severely injured population expected); non-con- } \\
\text { structive damage to buildings and facilities; local disruption of critical infrastructure; up to 1.2\% } \\
\text { expected economical losses from the municipal budget; necessity of medical care (up to 0.2\% of } \\
\text { affected population); loss of household income. }\end{array}$ \\
\hline High (74-86) & $\begin{array}{l}\text { Strongly affected population more than 0.3\%; necessity of medical care and temporary shelter; } \\
\text { structural and non-structural damage to buildings; cascading disruption of infrastructure; finan- } \\
\text { cial losses (economic damage); up to 5\% expected economic losses from the municipal budget. }\end{array}$ \\
\hline Very high (87-100) & $\begin{array}{l}\text { Victims and severely injured population (more than 0.5\% of the population); cascading disrup- } \\
\text { tion and failure of critical infrastructure; destroyed buildings and facilities; loss of household } \\
\text { income; necessity of medical care and temporary shelter; financial losses (economic damage) } \\
\text { more than 5\% of the budget. }\end{array}$ \\
\hline
\end{tabular}


methods, etc.), high consensus; 2) high: moderate evidence (several sources, some consistency, methods vary and/or documentation limited, etc.), medium consensus; 3) medium: suggestive evidence (a few sources, limited consistency, models incomplete, methods emerging, etc.), competing schools of thought; and 4) low: inconclusive evidence (limited sources, extrapolations, inconsistent findings, poor documentation and/or methods not tested, etc.), disagreement or lack of opinions among experts (https://science2017.globalchange.gov).

\section{CONCLUSIONS}

The present report describes a methodology for natural disaster risk assessment put in practice for Primorsko Municipality. Real scenarios derived from empirical data and analyses have been used. The final result shows low and very low risk levels; no death tolls are expected in case of the occurrence of landslides and earthquakes. Low and very low risk levels are due to low hazard and vulnerability levels and high coping capacity resources.

\section{Acknowledgements}

This study has been carried out in the framework of the project "Complex research, risk assessment and analysis of natural hazards in the territory of Primorsko Municipality”, upon the agreement between the Climate, Atmosphere and Water Research Institute at the Bulgarian Academy of Sciences and Primorsko Municipality. The author is grateful to Profs Nikolay Dobrev and Plamen Ivanov for their suggestions, reviews and comments.

\section{REFERENCES}

Berov, B., Ivanov, P., Dobrev, N., Krastanov, M. 2016. Addition to the method of Mora \& Vahrson for landslide susceptibility along the Bulgarian Black Sea coast. $12^{\text {th }}$ International Symposium on Landslides, Napoli, Italy, 12-19 June 2016, CRC Press, A Balkema book, 397-403, https://doi. org/10.1201/b21520-39.

Berov, B., Nikolova, N., Ivanov, P., Dobrev, N., Krastanov, M., Nankin, R. 2020. Landslide susceptibility mapping using GIS: a case study along Bulgarian Black Sea coast. $8^{\text {th }}$ International Conference on Cartography and GIS, 2020, Nesebar, Bulgaria, 287-296.

Blaikie, P., Cannon, T., Davis, I., Wisner, B. 1994. At Risk. Natural Hazards, People's Vulnerability and Disasters. Routledge, London, 496 pp.

Bruchev, I. 2018. Hazardous geological processes on the territory of the Republic of Bulgaria - conditions, factors, geoprotection. Engineering Geology and Hydrogeology 32, 57-64 (in Bulgarian, with English abstract).

Bruchev, I., Ivanov, P., Frangov, G., Varbanov, R., Dobrev, N., Berov, B., Nankin, R., Krastanov, M. 2007. The Landslides in Bulgaria - Factors and Distribution. Geologica Balcanica 36 (3-4), 3-12.

Dabovski, H., Kamenov, B., Sinnyovsky, D., Vasilev, E., Dimitrova, E., Bayraktarov, I. 2009. Upper Cretaceous geology. In: Zagorchev, I., Dabovski, Ch., Nikolov, T. (Eds), Geology of Bulgaria. Vol. II. Mesozoic geology. "Prof. Marin Drinov” Academic Press, Sofia, 303-589 (in Bulgarian, with English abstract).

Dobrev, N., Ivanov, P., Varbanov, R., Frangov, G., Berov, B., Bruchev, I., Krastanov, M., Nankin, R. 2013. Landslide problems in Bulgaria: factors, distribution and countermeasures. In: Landslide Science and Practice 7. Springer, Berlin-Heidelberg, 187-193, https://doi.org/10.1007/9783-642-31313-4_24.
Schmidt-Thomé, P. (Ed.). 2004. The Spatial Effects and Management of Natural and Technological Hazards in Europe - Executive Summary. Geological Survey of Finland, $173 \mathrm{pp}$.

Frangov, G., Zayakova, H., Hamova, M. 2011. Combined slope protection along the southern Bulgarian Black sea coast. Proceedings of the $15^{\text {th }}$ European Conference on Soil Mechanics and Geotechnical Engineering, Athens, 1343-1346.

Frantzova, A. 2017. Risk mapping methodology and classification for environmental hazards. LAP LAMBERT Academic Publishing, Chisinau, 120 pp.

IADB/GTZ. 2003. Comprehensive Risk Management by Communities and Local Governments. Component III; Indicator and other disaster risk management instrument for communities and local governments. Inter-American Development Bank for the Regional Policy Dialogue: Natural Disaster Network - III meeting. Preliminary Draft. Deutsche Gesellschaft für Technische Zusammenarbeit (GTZ) GmbH. Washington, D.C., 123 pp.

IADB. 2005. Indicators of Disaster Risk and Risk Management. Main Technical report. Program for Latin America and Caribbean. National University of Columbia - Manizales (Columbia), Institute of Environmental Studies. Washington D.C., 2005, 224 pp.

Iliev-Broutchev, I. (Ed.). 1994. Geological hazards in Bulgaria - Map in scale 1:500 000 and explanatory text. Military Topographic Service, Troyan/"Prof. Marin Drinov" Academic Press, Sofia, 143 pp. (in Bulgarian, with English abstract).

Ivanov, P., Berov, B., Dobrev, N., Krastanov, M., Frangov, S. 2017a. Principles for the assessment and mapping of integrated geological hazard in Bulgaria. Geologica Balcanica 46 (2), 103-109. 
Ivanov, P., Berov, B., Dobrev, N., Varbanov, R., Krastanov, M., Frangov, G. 2017b. Analysis and mapping of the landslide hazard in Bulgaria. Proceedings of the World Landslide Forum 4, May 29 - June 2, 2017, Ljubljana, 1111-1118, https://doi.org/10.1007/978-3-319-53498-5_126.

Ivanov, P., Dobrev, N., Berov, B., Krastanov, Nankin, R. 2020. Assessment of landslide hazard in Bulgaria using GIS. $8^{\text {th }}$ International Conference on Cartography and GIS 2020, Nesebar, Bulgaria, 297-305.

Konstantinov, B., Angelov, K., Lakov, A., Stojnev, S., Konstantinov, V. 1992. Landslides activation from earthquake motions. $6^{\text {th }}$ International Symposium on Landslides (ISL 1992), 1181-1186.

Lakov, A., Stoynev, S., Konstantinov, B. 2002. Geodynamic hazard and geodynamic risk along the Bulgarian Black Sea coast. Proceedings of the $9^{\text {th }}$ National Mine Surveying Conference with International Participation "Analysis, Modelling and Control of Geological Risk in Disturbed Territories”, 263-268 (in Bulgarian).

NIGGG. 2009. Seismic zoning of the Republic of Bulgaria, in accordance with the requirements of Eurocode 8 and maps development taking into account the seismic hazard on the territory of the country, Ministry of Regional Development and Public Works Sofia, 79 pp., https://www.mrrb.bg/static/ media/ups/articles/attachments/6abee694019e0a77523531 f237b5f72b.pdf (in Bulgarian).

Petrova, A., Dabovski, H., Mihailova, L., Savov, S., Chatalov, G. 1992. Geologic map of Bulgaria in scale 1:100 000, Tsarevo, Cape Silistar, Malko Tarnovo, Rezovo map sheet. Committee of Geology.

Poljansek, K., Casajus Valles, A., Marin Ferrer, M., Artes Vivancos, T., Boca, R., Bonadonna, C., Branco, A., Campanharo, W., De Jager, A., De Rigo, D., Dottori, F., Durrant, T., Estreguil, C., Ferrari, D., Frischknecht, C., Galbusera, L., Garcia Puerta, B., Giannopoulos, G., Girgin,
S., Gowland, R., Grecchi, R., Hernandez Ceballos, M.A., Iurlaro, G., Kampourakis, G., Karlos, V., Krausmann, E., Larcher, M., Lequarre, A.S., Libertà, G., Loughlin, S.C., Maianti, P., Mangione, D., Marques, A., Menoni, S., Montero Prieto, M., Naumann, G., Necci, A., Jacome Felix Oom, D., Pfieffer, H., Robuchon, M., Salamon, P., Sangiorgi, M., San-Miguel-Ayanz, J., Raposo De M., Do, N.E.S., De Sotto Mayor, M.L., Theocharidou, M., Theodoridis, G., Trueba Alonso, C., Tsionis, G., Vogt, J., Wood, M. 2021. Recommendations for National Risk Assessment for Disaster Risk Management in EU. Publications Office of the European Union, Luxembourg, http:// dx.doi.org/10.2760/80545.

Ranguelov, B. 2011. Natural Hazards - Nonlinearities and Assessment. "Prof. Marin Drinov" Academic Publishing House, Sofia, 327 pp.

Solakov D., Simeonova, S., Ardeleanu, L., Alexandrova, I., Trifonova, P., Cioflan, C. 2014. Hazard assessment for Romania-Bulgaria cross-border region. Comptes rendus de l'Académie bulgare des Sciences 67 (6), 835-842.

Simeonova, S., Solakov, D., Leydecker, G., Busche, H., Schmitt, T., Kaiser, D. 2006. Probabilistic seismic hazard map for Bulgaria as a basis for a new building code. Natural Hazards and Earth System Sciences 6 (6), 881-887, https://doi.org/10.5194/nhess-6-881-2006.

UNISDR. 2002. Living with risk. A Global Review of Disaster Reduction Initiatives. United Nations, Geneva, Switzerland, $429 \mathrm{pp}$.

UNDP. 2004. Reducing Disaster Risk. A Challenge for Development. United Nations Development Programme, Bureau for Crisis and Recovery, Geneva, Switzerland, $161 \mathrm{pp}$.

WGBU (German Advisory Council on Global Change). 1998. World in Transition: Strategies for Managing Global Environmental Risks. Annual Report 1998, Springer-Verlag, 359 pp., https://doi.org/10.1007/978-3-642-56958-6. 